\title{
A regional-scale groundwater flow model for the Leon-Chinandega aquifer, Nicaragua
}

\author{
Heyddy Calderón Palma • Laurence R. Bentley
}

\begin{abstract}
Groundwater flow in the Leon-Chinandega aquifer was simulated using transient and steady-state numerical models. This unconfined aquifer is located in an agricultural plain in northwest Nicaragua. Previous studies were restricted to determining groundwater availability for irrigation, overlooking the impacts of groundwater development. A sub-basin was selected to study the groundwater flow system and the effects of groundwater development using a numerical groundwater flow model (Visual MODFLOW). Hydrological parameters obtained from pumping tests were related to each hydrostratigraphic unit to assign the distribution of parameter values within each model layer. River discharge measurements were crucial for constraining recharge estimates and reducing the non-uniqueness of the model calibration. Steady-state models have limited usefulness because of the major variation of recharge and agricultural pumping during the wet and dry seasons. Model results indicate that pumping induces a decrease in base flow, depleting river discharge. This becomes critical during dry periods, when irrigation is highest. Transient modeling indicates that the response time of the aquifer is about one hydrologic year, which allows the development of management strategies within short time horizons. Considering further development of irrigated agriculture in the area, the numerical model can be a powerful tool for water resources management.
\end{abstract}

Received: 21 June 2006 / Accepted: 7 May 2007

(C) Springer-Verlag 2007

H. Calderón Palma (

Centro para la Investigación en Recursos Acuáticos de Nicaragua (CIRA/UNAN- Managua),

Enitel Villa Fontana, $400 \mathrm{~m}$ al Norte,

Managua, Nicaragua

e-mail: heyddy.calderon@cira-unan.edu.ni

Tel.: +505-278-6981

L. R. Bentley

University of Calgary,

2500 University Dr. NW,

Calgary, AB T2N 1N4, Canada

e-mail: lbentley@ucalgary.ca
Résumé L'écoulement des eaux souterraines dans l'aquifère Leon-Chinandega a été simulé grâce à des modèles numériques en régimes permanent et transitoire. Cet aquifère libre est situé dans une plaine agricole du Nord Ouest du Nicaragua. Des études précédentes se sont limitées à l'estimation de la ressource en eau disponible pour l'irrigation, sans tenir compte des impacts liés au développement des eaux souterraines. Un sous-bassin a été sélectionné pour étudier le système d'écoulement des eaux souterraines et les effets du développement des eaux souterraines à l'aide d'un modèle hydrogéologique numérique (Visual MODFLOW). Les paramètres hydrogéologiques obtenus à partir d'essais de pompage ont été reliés à chaque unité hydrostratigraphique pour procéder à la distribution des valeurs des paramètres au sein de chaque couche du modèle. Les mesures de débits de la rivière ont été cruciaux pour contraindre les estimations de la recharge et pour réduire la non-unicité de la calibration du modèle. Les modèles en régime permanent ont une utilité limitée car des variations majeures de la recharge et des pompages agricoles ont lieu pendant les saisons humides et sèches. Les résultats du modèle montrent que le pompage induit une diminution du débit de base, réduisant le débit de la rivière. Ceci devient critique lors des saisons sèches quand l'irrigation est plus importante. La modélisation en régime transitoire montre que le temps de réponse de l'aquifère est d'environ une année hydrologique, ce qui permet l'élaboration de stratégies de gestion sur des horizons de temps courts. Le modèle numérique peut constituer un outil de gestion des ressources en eau important compte tenu du développement potentiel de techniques d'agriculture irriguée plus sophistiquées dans la plaine Leon-Chinandega.

Resumen Se ha simulado el flujo de agua subterránea en el acuífero de León-Chinandega usando modelos numéricos en régimen permanente y régimen transitorio. Este acuífero no confinado se localiza en una planicie agrícola al noroeste de Nicaragua. Los estudios previos estuvieron restringidos a determinar el agua subterránea disponible para riego, pasando por alto los impactos del desarrollo de aguas subterráneas. Se seleccionó una sub-cuenca para estudiar el sistema de flujo de agua subterránea y los efectos del desarrollo de aguas subterráneas usando un modelo numérico de flujo de agua subterránea (MOD FLOW Visual). Los parámetros hidrológicos obtenidos de pruebas de bombeo se relacionaron a cada unidad 
hidroestratigráfica para asignar la distribución de los valores de los parámetros dentro de cada capa del modelo. Las mediciones de descarga en los ríos fueron decisivas para restringir las estimaciones de recarga y reducir la no unicidad de la calibración del modelo. Los modelos de régimen permanente tiene limitada utilidad debido a la variación fuerte de recarga y bombeo agrícola durante las estaciones húmeda y seca. Los resultados del modelo indican que el bombeo induce un descenso en el flujo base, agotando la descarga del río. Este proceso llega a ser crítico durante periodos secos cuando el riego es alto. El modelo transitorio indica que el tiempo de respuesta del acuífero es aproximadamente un año hidrológico lo cual permite el desarrollo de estrategias de gestión dentro de horizontes de tiempo corto. El modelo numérico puede ser una herramienta poderosa para la gestión de los recursos hídricos si se toma en cuenta el desarrollo potencial de agricultura de riego más sofisticada en la planicie de León-Chinandega.

Keywords Groundwater flow · Numerical modeling . Groundwater development · Nicaragua

\section{Introduction}

The Leon-Chinandega region is one of the most important agricultural regions in Nicaragua (Fig. 1). Irrigation is required due to a prolonged dry season. Only a small portion of the water used for irrigation comes from the rivers since the topography is not suited to dam construction. In addition, surface-water sources are unsuitable for human consumption due to contamination from agricultural chemicals and animal and human wastes. Consequently groundwater plays an important role for both irrigation and potable water supply.

Groundwater use for large-scale irrigation has been assessed in previous works; however, sustainability and contamination issues were not addressed. The United Nations (United Nations 1974) conducted a study to determine the feasibility of groundwater use for largescale irrigation. It concluded that the most suitable use of this large aquifer was groundwater extraction through production wells, which would allow intensive use of the land. At that time, cotton and sugar cane were the main cultivated crops in the region and represented the bulk of the country's exports. Irrigation would both increase and stabilize agricultural production, which traditionally depended on the rainy season. The Nicaraguan Institute for Territorial Studies (INETER 2000) carried out a hydrogeological study to assess the availability of the water resources in the Pacific Coast region of the country for the development of irrigated agriculture. The study focused on a quantitative assessment of the potential of the aquifer as a source of water for irrigation. The study also included the first attempt to develop a steady-state model for a sub-basin of the aquifer, but little consideration was given to the effects of groundwater development. Agrochemical contamination has been addressed by several authors (Briemberg 1994; CIRA 1999a, b; Centro
Humboldt 2001; Delgado 2003). The studies focused mainly on the distribution of organochlorine and organophosphate pesticides used in cotton cultivation from the 1950 s until the early $1980 \mathrm{~s}$.

The purpose of this work is to study the groundwater flow system in a sub-basin of the Leon-Chinandega aquifer using transient and steady-state numerical groundwater-flow models and to investigate the effects of further groundwater development. Transient simulations were conducted for the first time for the aquifer, since the usefulness of the results of steady-state simulations in this region is limited because of the large differences in recharge and flow conditions between the wet and the dry seasons. In addition, the conceptual model was improved by adding new information and the numerical model used new calibration data, including base-flow measurements, to improve its performance.

\section{Study area}

The area selected for the numerical model is a $330 \mathrm{~km}^{2}$ subbasin (Fig. 1b), which extends from the Pacific Ocean coast through the Leon-Chinandega plain towards the Marrabios Cordillera at 900 meters above sea level (masl; Fig. 2). The study area was selected because it contains the town of Posoltega and regions of intensive irrigated agriculture. The study area is situated between the Sucio and Telica rivers.

Nicaragua has a dry season from November to April and a rainy season from May to October. Precipitation is highest during June, September and October. There is also a short period during the rainy season when precipitation decreases considerably called canicula. Annual precipitation in the Leon-Chinandega region ranges from 1,200 $\mathrm{mm}$ in the lowest areas by the coast to more than 2,000 $\mathrm{mm}$ in the Cordillera (INETER 2000).

The Leon-Chinandega aquifer is found in two geologic provinces: the Pacific Coast Belt and the Great Nicaraguan Depression. The Pacific Coast Belt comprises two geomorphologic units, the large volcanic plain of Leon-Chinandega and the ignimbrite hills of the Tamarindo Plateaus. The Great Nicaraguan Depression or Nicaraguan Graben is a wide, shallow, structural valley located within two sets of NW-SE trending normal faults. The graben is made up of the Marrabios Cordillera, a volcanic range with NW-SW orientation, and the Lakes of Managua and Nicaragua.

The stratigraphy of the study area is comprised of the following descending sequence:

1. Marsh and coastal deposits comprised of limey-clayey sands.

2. Pyroclastic and alluvial deposits, formed by eruption products of the volcanoes of the Marrabios Cordillera.

3. Las Sierras Formation composed of pyroclastic sediments with a maximum known thickness of $220 \mathrm{~m}$.

4. The Tamarindo Formation comprised of tuffs, ignimbrites, basalts and andesites. It is the oldest strata within the aquifer and is considered impermeable. Outcrops appear near the coast and at the northwest, western and eastern parts of the aquifer area. 
Fig. 1 a Aquifer location map b The Leon-Chinandega aquifer and the modeled sub-basin a

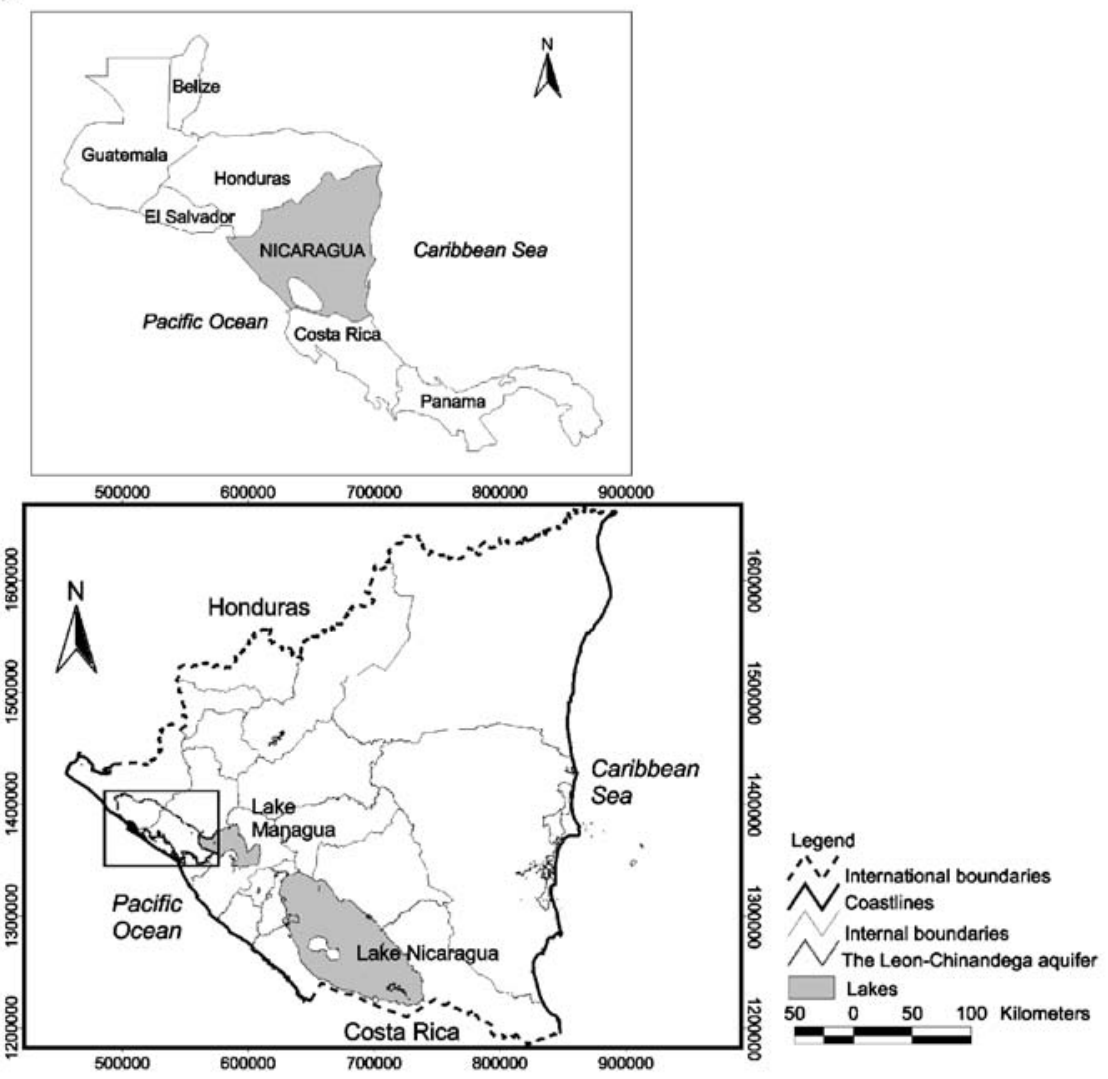

b

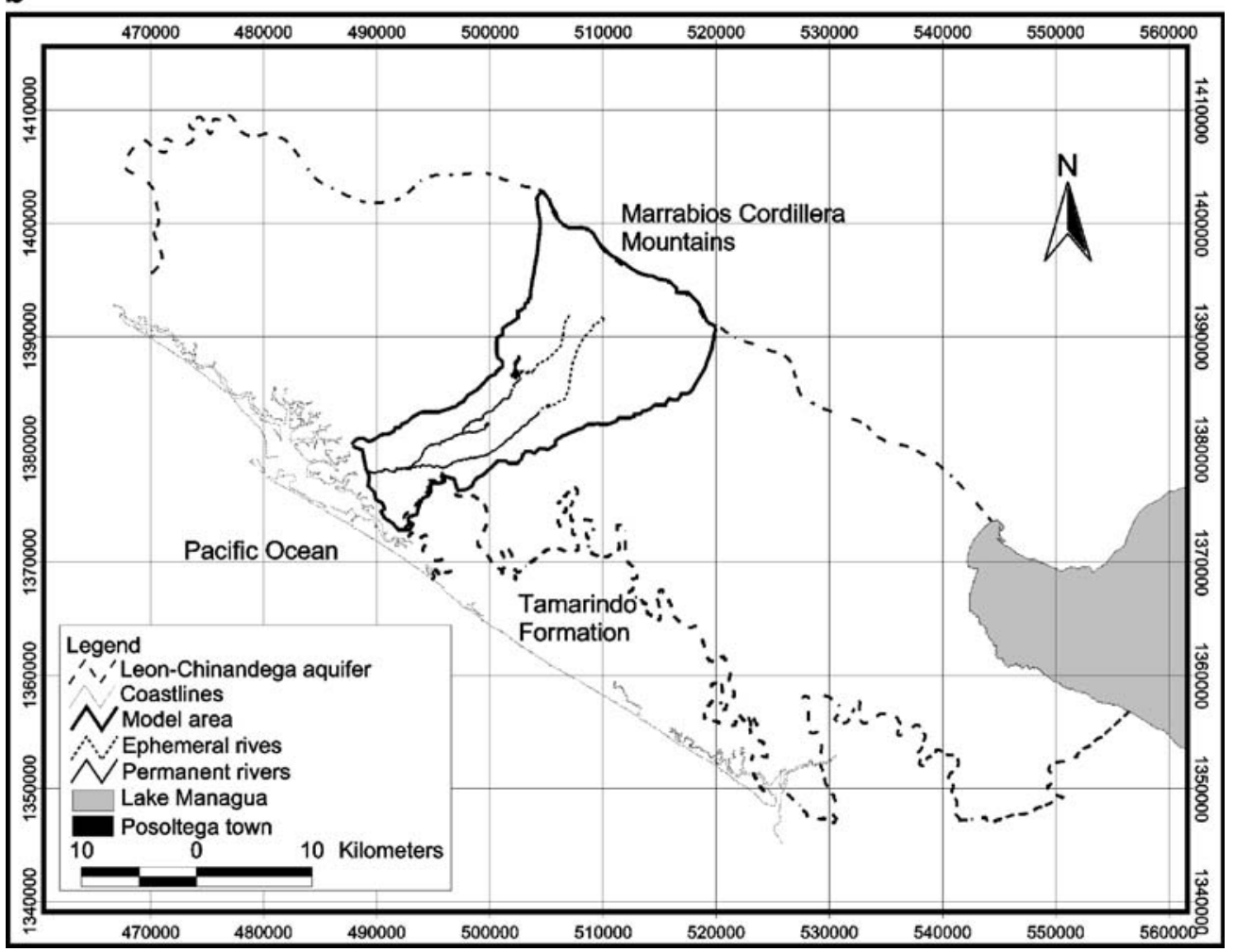

Groundwater contamination by pesticides has been identified as a significant issue in the Leon-Chinandega aquifer (Fenzl 1985; Briemberg 1994; Castillo 1994; Carvalho et al. 1999; CIRA 1999a, b; Centro Humboldt 2001; Delgado
2003). Greater concentrations and more types of organochlorine pesticides are observed in shallow dug wells than in the deeper drilled wells (Corriols 2003). Pesticide contamination has been found at depths of up to $12 \mathrm{~m}$ below the water table 
Fig. 2 Posoltega study area

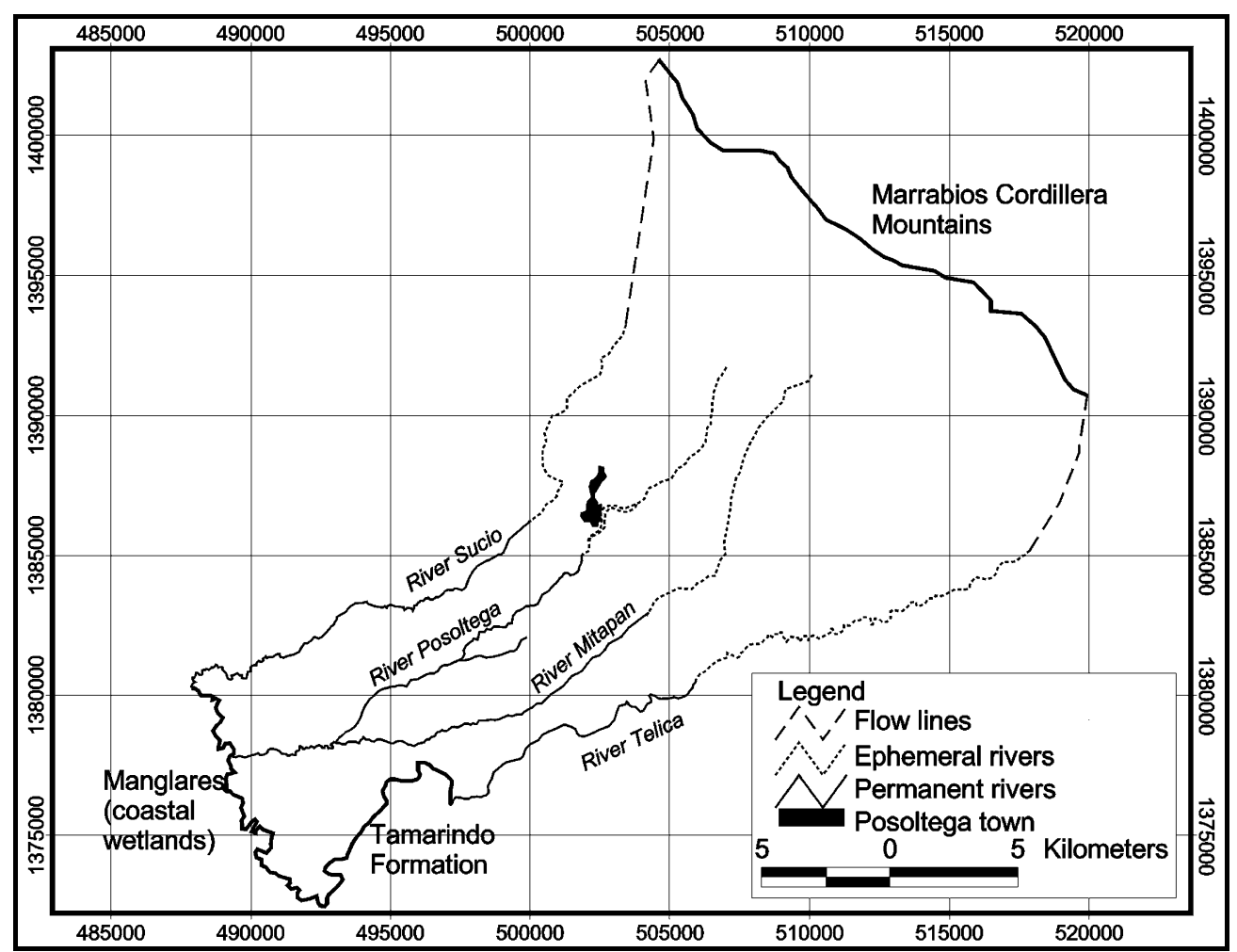

(Delgado 2003). Water from the deeper portion of the aquifer has oxygen 18 and deuterium signatures that are consistent with water being recharged in the uplands of the Marrabios Cordillera whereas water from the shallower portion of the aquifer has isotopic signatures consistent with water being recharged in the Leon-Chinandega plain (Payne and Yurtsever 1974; Delgado 2003). However, there is some mixing of the local and regional recharge according to isotope results (Corriols 2003; Delgado 2003). This mixing might be accentuated by the over pumping of deep wells, increasing the risk of contamination of the deeper zones of the aquifer (Calderon 2004).

\section{Conceptual model}

\section{Hydrogeology}

The Leon-Chinandega aquifer is an unconfined aquifer bounded by the Marrabios Cordillera, the Pacific Ocean and contacts with impermeable formations such as the Tamarindo Formation (Figs. $1 \mathrm{~b}$ and 2). The water-table depth ranges from a couple of meters near the coast to more than $100 \mathrm{~m}$ in the foothills of the volcanoes. Seasonal fluctuations in the phreatic surface are more noticeable where the water table is shallow. A rise in water levels starts almost at the beginning of the rainy season. This same process starts about 3.5-4.5 months later in the areas where the water table is below $20 \mathrm{~m}$ depth. The decline in water levels shows the same behavior; it starts at the end of the rainy season in the shallow groundwater areas and from 4 to 4.5 months later in the deeper groundwater areas (United Nations 1974). It has been reported that transmissivity $(T)$ values for the aquifer range from 500 to
$7,000 \mathrm{~m}^{2} /$ day. Storage $(S)$ estimates range from 0.01 to 0.1 . These parameters were estimated from 26 pumping tests analyzed using the Walton-Kozeny and Jacob methods (INETER 2000). The United Nations (United Nations 1974) reported a minimum value of $33 \mathrm{~m}^{2}$ /day and a maximum of $7,100 \mathrm{~m}^{2} /$ day for transmissivity using the Boulton method on 47 pumping tests. Also according to United Nations 1974, transmissivity increases from the coast to the foothills of the Marrabios Cordillera. Values between 300 and $500 \mathrm{~m}^{2} /$ day are found in the lower part of the plain, increasing to $1,500 \mathrm{~m}^{2} /$ day in the central part and reaching $3,000-5,000 \mathrm{~m}^{2} /$ day in the higher areas greater than 100 masl. Storage has the same trend, increasing from 0.02 to 0.35 (United Nations 1974).

\section{Recharge and discharge}

Natural recharge occurs directly as infiltration from precipitation. Other forms of recharge are excess irrigation, which is not evapotranspired, and losses from the municipal water supply systems. Four recharge zones were defined based on soil types (INETER 2000). In that study, water-balance calculations were made for each type of soil present and natural recharge was estimated as a percentage of precipitation, after accounting for evapotranspiration. The highest recharge zone, zone 3 , is the sandy and coarser soils of the volcanic foothills above 150 masl (Fig. 3a). Recharge in this zone was estimated as $42 \%$ of mean annual precipitation (MAP). In recharge zone 2, recharge is about $28 \%$ of the MAP. The zone is comprised of sandy soils and it is found approximately between 20 and 150 masl. Zone 1 corresponds to clayey soils and; it is located between the manglares or coastal 


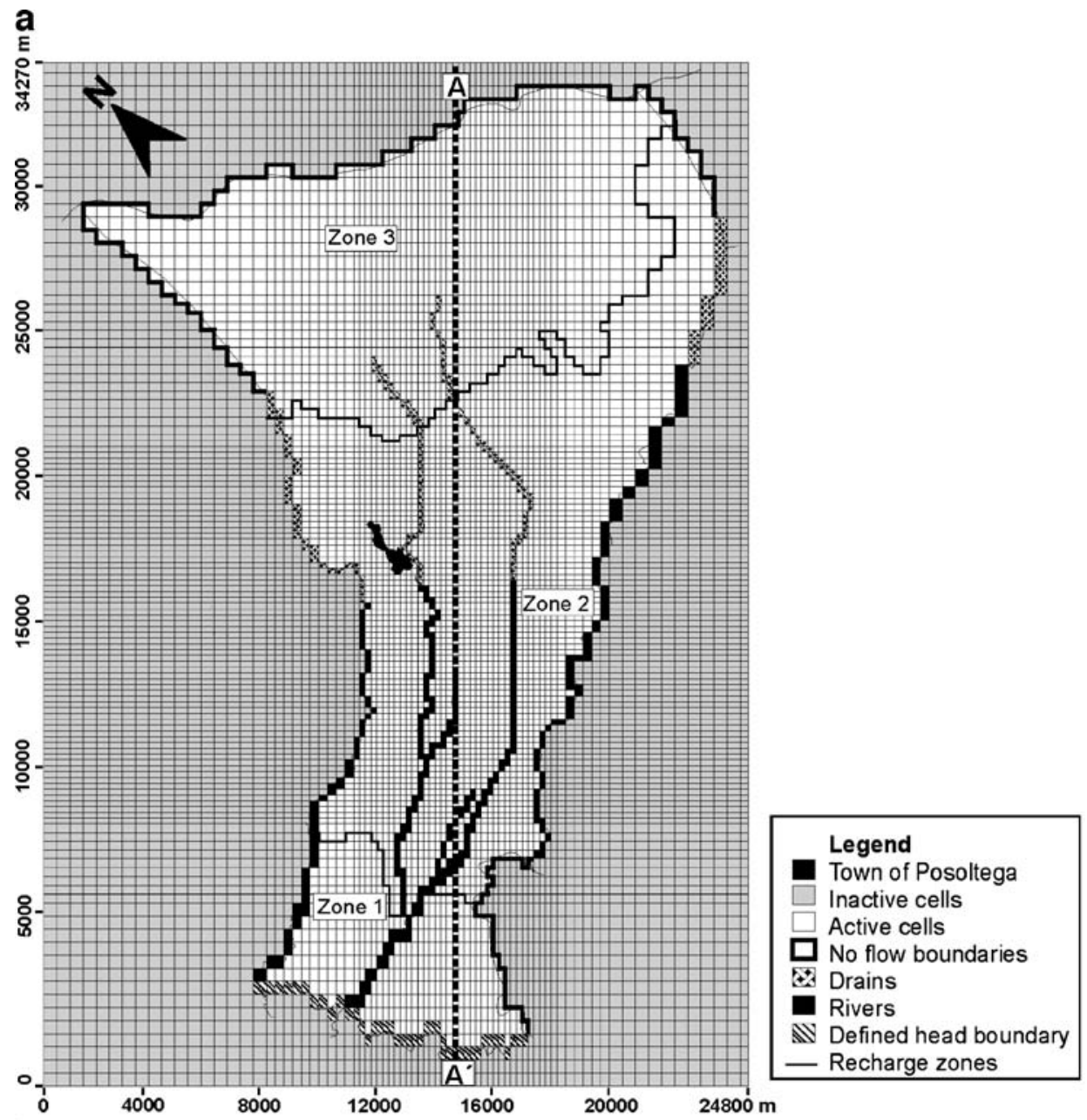

b

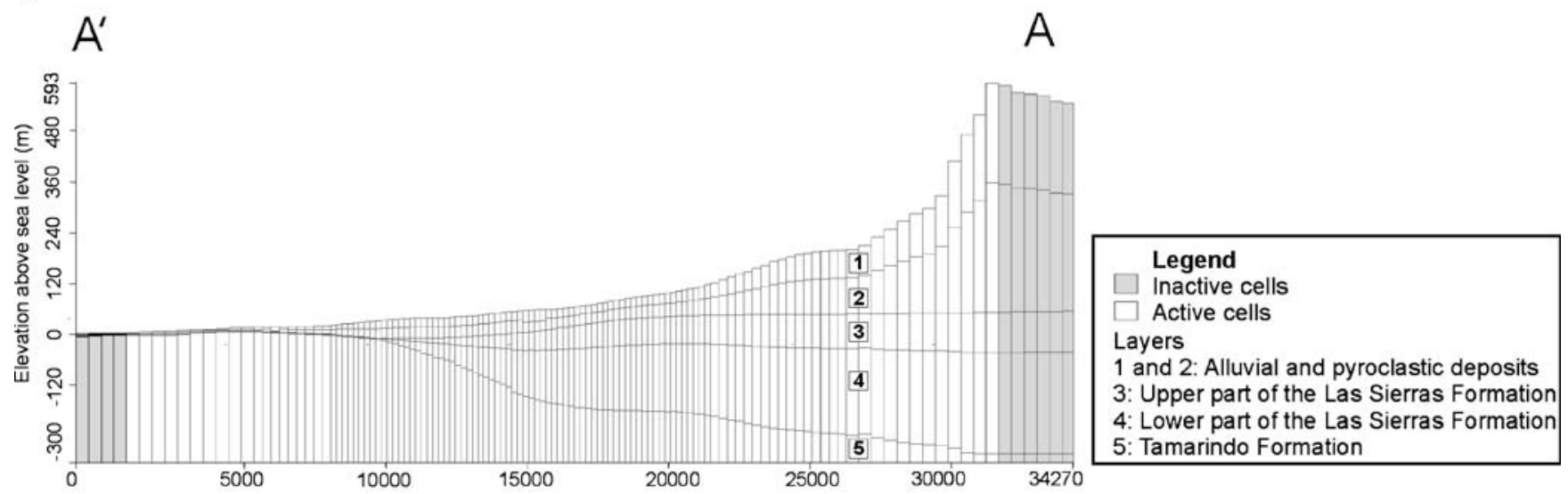

Distance along transect $(\mathrm{m})$

Fig. 3 a Model grid, model boundaries and recharge zones (layer 1). Map in model coordinates (meters). b Model cross section A'A with five grid layers. The top two layers represent the pyroclastic and alluvial deposits, followed by the upper and lower Las Sierras Formation and the Tamarindo Formation, respectively. Map in model coordinates

wetlands and the 20 masl contour and its estimated recharge is about $10 \%$ of the MAP. The no-recharge zone was defined as the area between the limits of the wetlands and Pacific Ocean coast, which is approximately below the $10 \mathrm{~m}$ elevation contour. This zone is not included in the model. INETER (2000) estimated the losses from excess irrigation as $25 \%$ of the total volume. The United Nations (1974) estimated that recharge from the water 
supply system is $34 \%$ of the total supply and recharge from irrigation is $27 \%$ of the total volume irrigated. The model assumed an initial value of $30 \%$ of the groundwater extracted as aquifer recharge, but this value was later modified to $10 \%$ to achieve better calibration.

Most of the aquifer discharge occurs as river base flow, which is the biggest provider of river discharge (United Nations 1974). The rivers included in the study area are very well connected to the aquifer.

Groundwater is withdrawn from the aquifer through drilled and dug wells. Dug wells are used for domestic supply where there are no water supply systems in place. These wells are usually shallow and the volumes extracted from them are insignificant compared to drilled wells. Deeper drilled wells are used for irrigation and public water supply and are generally screened at depths ranging from 20 to $60 \mathrm{~m}$ below the surface. Irrigation takes place during the dry season and during periods of low precipitation. Groundwater extraction records from the UN report (United Nations 1974) were used for the 1965-1975 and the 19701971 models. The extraction records for the 1999 model were provided by the sugar mill Ingenio San Antonio, which owns most of the private wells in the area. Records for public water supply wells were not available, thus personal interviews with well keepers were conducted to determine extraction rates. This information was combined with the INETER (2000) report.

\section{Hydrostratigraphic units}

Four hydrostratigraphic units were defined for the LeonChinandega aquifer. Three aquifer layers were defined in addition to the impermeable basement (Fig. 3b), based on the geology and hydraulic parameters. The units are in descending order:

1. Alluvium and pyroclastic deposits. These materials have excellent transmissivity and storage properties and form very good aquifers (layers 1 and 2).

2. Upper part of the Las Sierras Formation. This unit has properties similar to the alluvial and pyroclastic deposits (layer 3).

3. Lower part of the Las Sierras Formation. The unit has lower hydraulic conductivity than the upper part due to the compaction of materials. The location of the boundary between the upper and lower parts of the Las Sierras Formation is poorly constrained (layer 4).

4. Tamarindo Formation. This formation is composed of low hydraulic conductivity materials such as ignimbrites and basalts (layer 5).

\section{Numerical model}

The code selected to develop the numerical model was MODFLOW; a modular, three-dimensional finite difference groundwater flow model developed by the US Geological Surey (McDonald and Harbaugh 1988). The version used in this work is Visual MODFLOW 2.8.2.

\section{Model domain and discretization}

A groundwater sub-basin of the Leon-Chinandega aquifer was selected as the domain for the numerical groundwater model (Fig. 2). The domain has an approximate area of $330 \mathrm{~km}^{2}$. The model grid is formed by 5,200 cells per layer. The cells are $200 \times 200 \mathrm{~m}$ in the more refined zones (Fig. 3a). The grid was refined at the center of the domain where more pumping occurs. Grid spacing increases up to $450 \times 450 \mathrm{~m}$ away from towns where less stresses are expected. The cell dimensions were increased by a factor of 1.5 to avoid excessive truncation errors in the solution of the groundwater flow equation (Anderson and Woessner 1992). The model grid was oriented from NE-SW, following the general groundwater flow direction. Layer 1 was represented by the upper two grid layers in order to appropriately model the upper river reaches (Fig. 3b). The remaining three hydrostratigraphic units are represented by single layers in the numerical model.

\section{Boundaries}

The model area is located between the Sucio and Telica rivers, which act as physical boundaries in the first layer of the model with the head set to the river elevation (Fig. 3a). The origins of the Telica and Sucio rivers are located at about 50-60 masl. Drain boundary conditions in the top layer were used along the ephemeral sections of the two rivers. Drain nodes allow discharge to the cell when head values are greater than the head in the cell, but do not allow water to flow into the aquifer. A no-flow boundary condition was assigned to the upper layer along the dry beds between the Cordillera and the ephemeral part of the rivers. Layers underlying the river and the upstream ephemeral and dry channels were assigned no-flow boundaries on the assumption that the rivers act as hydraulic boundaries.

The watershed divide of the Marrabios Cordillera is defined as a no-flow boundary. The manglares is a discharge zone and the water table is very close to ground surface, thus this boundary was defined as a constant head boundary (Fig. 3a). The lowest formation, the Tamarindo Formation, has very low permeability, but it is included in the model. The lower no-flow boundary of the model is the bottom of the Tamarindo Formation based on the assumption that the low permeability of the Tamarindo Formation will allow minimal flow.

\section{Internal boundaries}

There are two rivers inside the model area, the Posoltega and the Mitapan rivers (Fig. 2). River boundaries were represented by the Cauchy mathematical condition or head dependent flow boundary for which flow across the boundary is calculated given a boundary head value. This was simulated using the river package included in Visual MODFLOW.

A topographic survey was performed in several reaches along the Posoltega River (Calderon 2004). These measurements provided accurate river bottom and river stage elevation data. Drain nodes were used inside the 
model area to simulate the upper reaches of both the Posoltega and Mitapan rivers. The river elevations were obtained from topographic maps.

Rivers were simulated as Cauchy condition using the river package included in Visual MODLOW. The data requirements to model a river include river stage elevation, river bottom elevation and a streambed conductance. This latter term includes river channel parameters such as length, width and riverbed thickness as well as hydraulic conductivity of the streambed sediments. Conductance is determined by the following equation:

$$
\mathrm{CRIV}=\frac{\mathrm{K}_{\mathrm{r}} L W}{M}
$$

\section{where}

$\begin{array}{ll}\text { CRIV } & \text { streambed conductance }\left(L^{2} / T\right) \\ K_{\mathrm{r}} & \text { hydraulic conductivity of streambed material } \\ & (L / T) \\ L & \text { stream length }(L) \\ W & \text { stream width }(L) \\ M & \text { thickness of the streambed layer }(L)\end{array}$

Attempts to estimate $K_{\mathrm{r}}$ were made through slug tests in mini-piezometers, but water levels dropped too fast to obtain accurate measurements. Thus, $K_{\mathrm{r}}$ was assumed based on values reported for clean sand (Freeze and Cherry 1979). The value used was $10 \mathrm{~m} /$ day. Stream width was known for the reaches where the elevation measurements took place. Interpolation between the points of measurements completed the data needed. Streambed thickness was assumed constant and equal to $1 \mathrm{~m}$. Stream length is determined by the length of the cells, varying from 200 to $450 \mathrm{~m}$, depending on grid spacing. No data were available for the other river because of the high cost of topographic measurements and access problems. Therefore, the same parameters from the Posoltega River were used, based on the similar features of these rivers. Streambed conductance values range from 27,090 to $85,500 \mathrm{~m}^{2} /$ day.

\section{Hydraulic parameters}

Hydraulic conductivity $(K)$ estimates were obtained from 54 pumping tests (United Nations 1974; INETER 2000 and individual drilling reports). Originally, 11 of these tests were analyzed using the Boulton method (United Nations 1974). However, since the data presented delayed yield response, the Neuman method (Neuman 1975) was used to re-analyze the data (Calderon 2004).

INETER (2000) reported 37 tests analyzed with the Jacob and Walton-Kozeny methods. Full records of these tests were not available; therefore, re-analysis of the estimates was not possible. The remaining tests were gathered from individual drilling reports where Jacob and Theis methods were used for analysis. Transmissivity values were divided by the length of the water column in the monitored well to obtain hydraulic conductivity estimates. However, $K$ estimates may be biased towards larger values since they may correspond to the most productive zones within the aquifer, where the wells are usually screened. Furthermore, observation wells were not used in most of the pumping tests and only the pumped well was monitored. Single well tests produce unreliable storage-coefficient estimates and are not as accurate as tests using monitoring wells. Despite these limitations the hydraulic conductivity estimates are regarded as good initial values for the numerical groundwater model. If it is considered that this parameter may range over 13 orders of magnitude, an order-of-magnitude knowledge of this property can be very useful (Freeze and Cherry 1979).

Once the hydraulic parameter database was completed, conductivity values were assigned to each of the hydrostratigraphic layers identified in the aquifer. The vertical distribution was achieved by locating the well screen intervals in the appropriate layer of the aquifer. The horizontal distribution of hydraulic conductivity was obtained by allocating each estimate according to the pumping well coordinates. For the alluvial and pyroclastic deposits and the upper Las Sierras Formation, kriging was undertaken on the values of each layer, using SURFER 7.0 (a contouring and three-dimensional surface mapping package), to obtain hydraulic conductivity contours which were used to define $K$ zones. Each zone was assigned an average $K$ value (Calderon 2004).

The lower member of the Las Sierras Formation did not have enough data points and was assigned a single value which was the average of five available estimates. $K$ values range from 15 to $300 \mathrm{~m} /$ day in the pyroclastic and alluvial deposits and from 15 to $60 \mathrm{~m} /$ day in the upper Las Sierras Formation. The lower Las Sierras Formation was assigned an average value of $6 \mathrm{~m} /$ day. The difference in values assigned to the upper and lower parts of the Las Sierras Formation is most probably caused by the difference in compaction (United Nations 1974). No hydraulic conductivity estimates were available for the Tamarindo Formation and it was assumed to have a $K$ value of $0.001 \mathrm{~m} /$ day based on the impermeable nature of the geologic materials. This assumption essentially means a no-flow condition for the lower Las Sierras Formation-Tamarindo Formation interface (Anderson and Woessner 1992).

Estimates for the storage coefficient $(S)$ for the LeonChinandega aquifer range from 0.02 to 0.35 , with an average of 0.10 (United Nations 1974). These values are consistent with unconfined aquifers, which have specific yield values (Sy) between 0.01 and 0.3 (Freeze and Cherry 1979). The average value reported by the UN was used in the model $(\mathrm{Sy}=0.1)$.

\section{Recharge and groundwater extractions}

The recharge estimates reported by INETER (2000) as percentages of the mean annual precipitation (MAP) were used in the model as initial values. Precipitation in zone 3 is higher due to an orographic effect (Table 1). However, the amount of recharge ( $\mathrm{mm} /$ year) was slightly modified 
Table 1 Recharge values

\begin{tabular}{lll}
\hline $\begin{array}{l}\text { Recharge } \\
\text { zone }\end{array}$ & $\begin{array}{l}\text { Recharge INETER } \\
\text { (2000; \% of MAP) }\end{array}$ & $\begin{array}{l}\text { Calibrated recharge } \\
\text { (\% of MAP) }\end{array}$ \\
\hline 1 & 10 & 10 \\
2 & 28 & 34 \\
3 & 42 & 40 \\
\hline
\end{tabular}

during calibration, with the value in zone 2 increasing from 28 to $34 \%$ of the MAP The recharge zone distribution is shown in Fig. 3 a.

\section{Modeling approach}

A steady-state model was developed to study regional flow patterns in the aquifer and to calibrate the model's recharge and transmissivity. A transient model was also developed because the amount of precipitation, and consequently recharge, varies significantly between the wet and dry seasons as well as from year to year. Steadystate models cannot account for these variations and a transient state model was developed to study the cyclic fluctuations in the water table and investigate their effects on flow patterns. Groundwater extraction is also a changing stress, which increases as population grows and more irrigated agriculture is developed.

Results from five different scenarios are reported:

1. Steady state, modern pumping conditions (1999)

2. Steady state, low pumping conditions (1965-1975)

3. Transient, (1970-1971)

4. Transient, (2004-2005)

5. Transient, additional groundwater development

The first four scenarios were used to calibrate and verify the model as well as to examine the general response of the groundwater flow system. The steady-state model was calibrated using data from 1999 (scenario 1), and then this model was verified by simulating the 1965-1975 field data using the same set of calibrated parameter values and the precipitation and pumping values estimated for the 1965 1975 time period (scenario 2). Starting parameters were estimated from test results and historical records and recharge was adjusted during the calibration procedure within reasonable bounds. The purpose of model verification is to establish greater confidence in the model by demonstrating the accuracy and predictive capability of the model using data other than the calibration targets (Anderson and Woessner 1992). Verification allows us to test the consistency of parameter estimates and model reliability. Calibration results and verification results are shown in Fig. 4a and $b$, respectively.

The purpose of simulating scenario 3 is to study the cyclic fluctuations in the water table reported by United Nations (1974). Scenario 3 is also a verification test for the steadystate model because conductivities and recharge percentages determined during the steady-state calibration were used to simulate the transient state response. Average monthly precipitation values (expressed in $\mathrm{mm} /$ year) were calculated using precipitation records (United Nations 1974) and recharge was estimated using values from Table 1. Scenario 4 is a further verification of the transient state model that used additional field measurements from 2004 and 2005 (Moncrieff 2006). The observation wells were limited to the surroundings of the town of Posoltega since they were monitored to develop a smaller scale model for another work (Moncrieff 2006). The use of river base flow values in the verification provides a strong constraint on the recharge values since most of the recharge is eventually discharged as base flow. Using base flow to constrain the recharge significantly reduces the non-uniqueness that is often associated with mildly heterogeneous aquifers that are only calibrated to hydraulic head data. Finally, scenario 5 was used to analyze the effect of changes in groundwater extraction.

\section{Results}

\section{Model calibration}

Some of the initial parameter values were modified to achieve better calibration of the model. Recharge in zone 2 was increased from the initial estimate of 28 to $34 \%$ of the MAP and it was decreased from 42 to $40 \%$ of the MAP in zone 3. Hydraulic conductivity was increased in some areas of layer 1 by about $20 \%$. These changes are consistent with the conceptual model and are within reasonable ranges.

Calculated vs. observed hydraulic head cross-plots (Fig. 4) show a good correlation between observed and simulated heads. However, the hydraulic heads in the upland areas have been somewhat under predicted in scenarios 2 and 3 (Fig. 4b and c, respectively). The verification results from the last stress period are shown for the transient state model (Fig. $4 \mathrm{c}$ and d). The locations of observation wells used in each scenario cross plot are presented in Fig. 5.

River base flow residuals (Table 2) also indicate that the model is reasonably well calibrated. The river base flow value simulated for 1970-1971 was compared to the average for the hydrologic year 1970-1971. The simulated value for 2004-2005 was compared to field measurements (Fig. 6) and to the average for that year (Table 2); however, the measured average might be biased (too low) because only eight monthly measurements were made (Fig. 6). Furthermore, the large volumes of surface water used for irrigation during dry months were not accounted for in field measurements. There are no records for river-water use and irrigation occurs without any control from local authorities.

The transient simulations were run for 10 years, using the results from either 1970-1971 or 2004-2005 to remove the influence of the steady-state simulation initial condition. The results of the tenth cycle are reported. The influence of the initial conditions is not observed after the first year of the transient simulation (Fig. 7), indicating that the "memory" within the basin is on the order of 1 year. The amplitude of the modeled hydraulic head 
Fig. 4 a Calculated vs. observed hydraulic heads for 1999 model (steady state). For observation well locations, see Fig. 5a. b Calculated vs. observed hydraulic heads for 1965-1975 model (steady state). For observation well locations, see Fig. 5b. c Calculated vs. observed hydraulic heads for the end of the 1971 dry season (April). For observation well locations, see Fig. 5b. d Calculated vs. observed hydraulic heads for the end of the 2005 dry season (April). For observation well locations, see Fig. 5c a

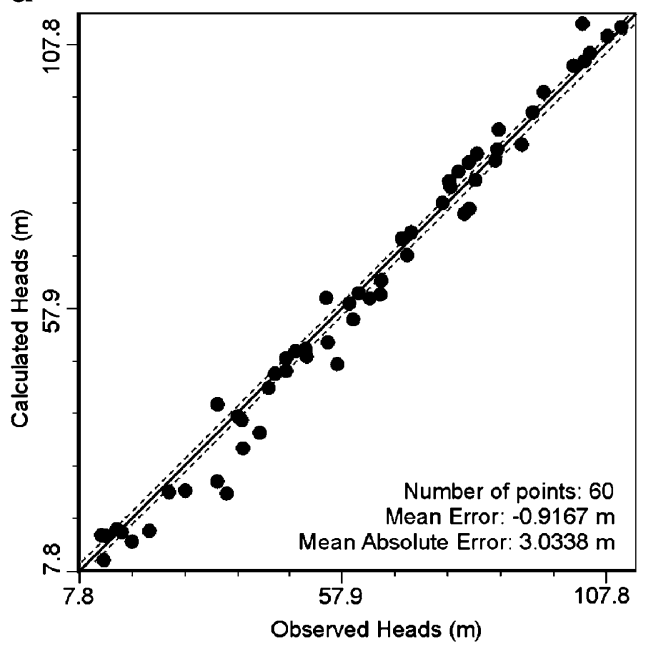

C

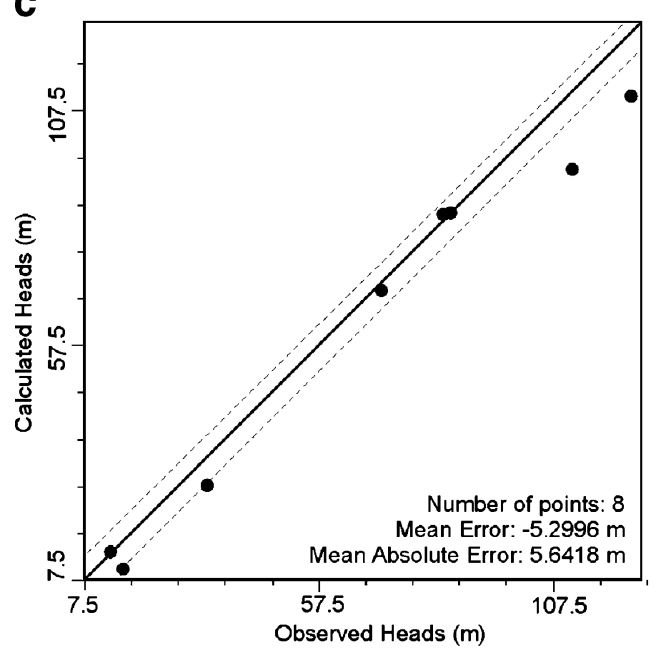

b

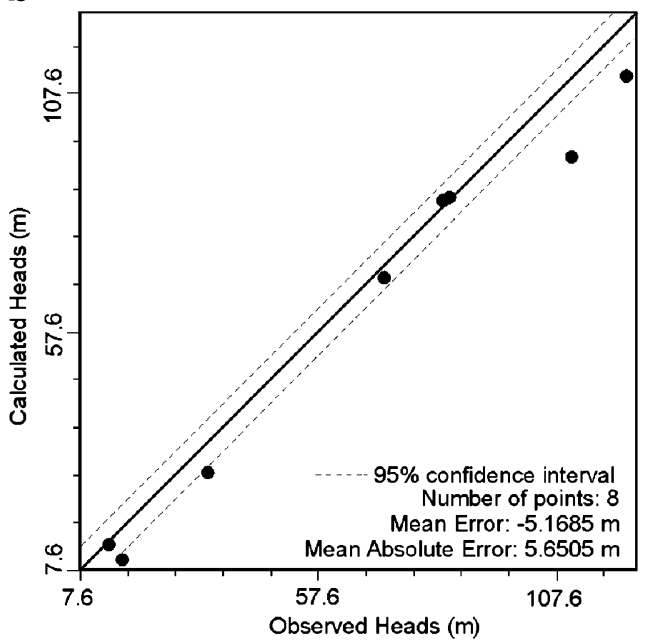

d

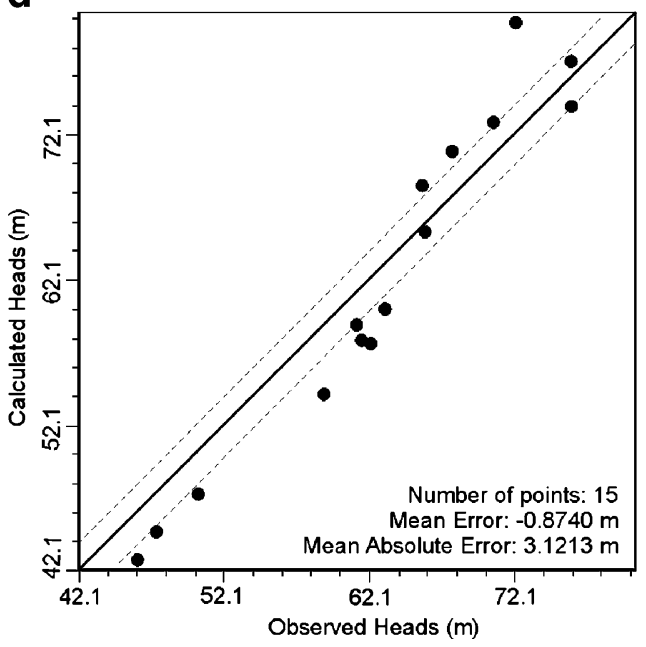

fluctuations in the higher elevation region was overestimated by the initial 1970-1971 transient model (Calderon 2004). Simulated head values located at the highest elevations showed peak hydraulic-head values occurring at the end of the rainy season, whereas field observations show a lag of about 3.5-4.5 months for the head values to peak in the areas where the water table is deeper than $60 \mathrm{~m}$ (United Nations 1974). The observed response of the water table to changes in precipitation is immediate in shallow groundwater areas in which the water table is less than $30 \mathrm{~m}$. In addition, the amplitude of the observed fluctuations is less in the highlands than in the lowlands. The delayed response and dampened amplitude of hydraulic heads to recharge as seen in observation well hydrographs (United Nations 1974) are likely to be due to groundwater recharge passing through a thick vadose zone. The water-table depth in the higher elevation areas is about $100 \mathrm{~m}$ (United Nations 1974; INETER 2000). Heterogeneities such as lenses or sloping interfaces between layers of contrasting hydraulic properties can divert the downward vertical path of seepage (Stephens 1996). Clay layers may impede downward movement of water through thick vadose zones reducing the effect of seasonal recharge (Izbicki et al. 2000, 2002).

In order to better model the upland recharge, a non time-varying infiltration rate that is a percentage of the annual precipitation was assumed in the upland areas. That is, a constant recharge rate was applied throughout the simulation period to recharge zones 2 and 3. This change improved the simulation of the fluctuation in the upland wells (Fig. 8). This approach has been used before in mountainous terrain where patterns of recharge at the water table could be different from infiltration patterns when there is significant lateral flow in the vadose zone (Forster and Smith 1988a, b). The lowlands continued to have time varying recharge applied as a percentage of average monthly precipitation.

\section{Sensitivity analysis}

Sensitivity analysis was performed by systematically changing parameter values and examining the effect of these changes on the model results. The mean absolute error (MAE) and the river base flow residual (calculated- 

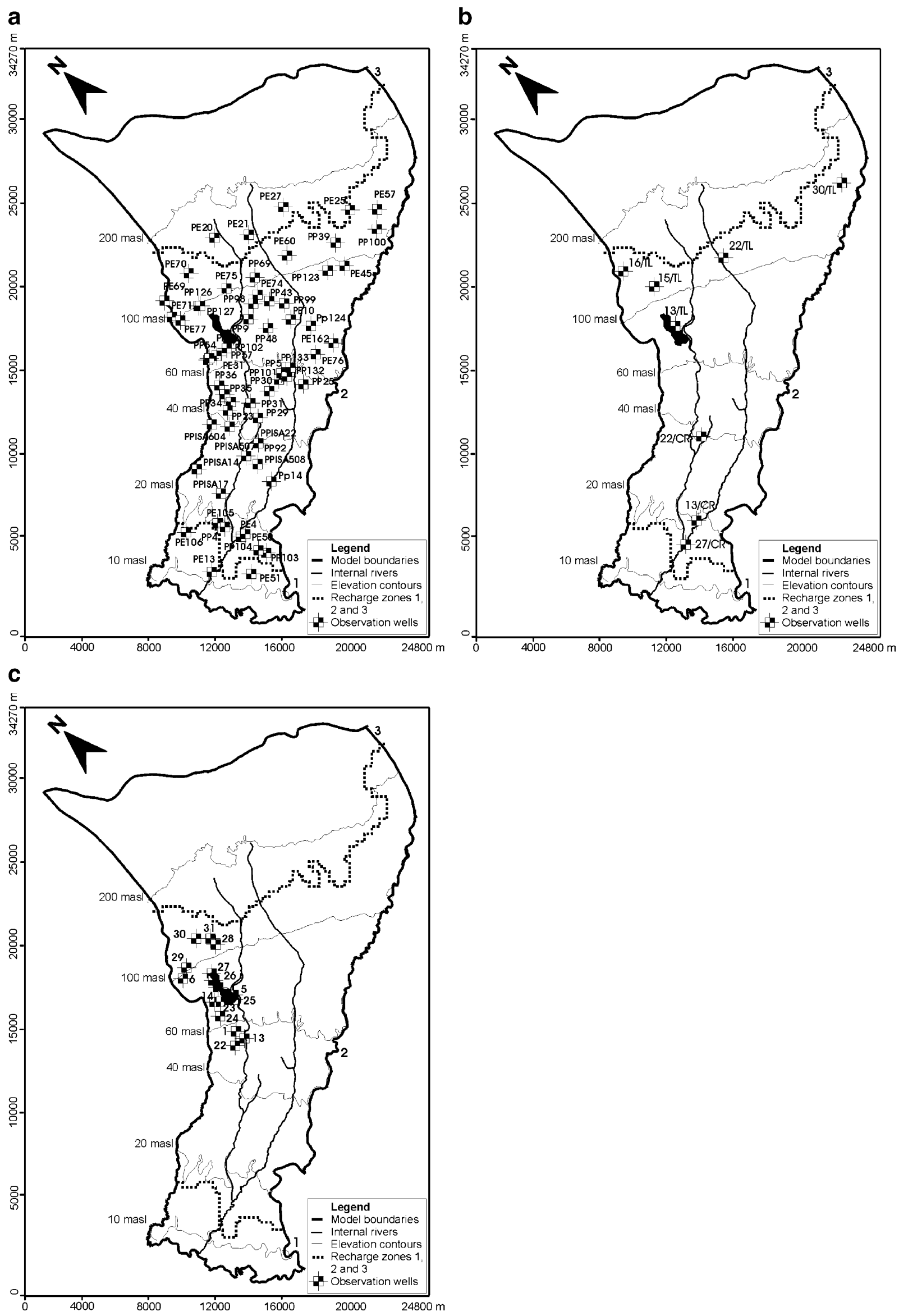
Fig. 5 a Observation wells for the 1999 model, from INETER 2000 (masl: meters above sea level). Map in model coordinates. b Observation wells for the 1965-1975 and 1970-1971 models, from UN 1974 (masl: meters above sea level). Map in model coordinates. c. Observation wells for 2004-2005 model, from Moncrieff 2006 (masl). Map in model coordinates

observed base flow) were plotted against the parameter changes to compare their effect on the model. The sensitivity analysis was exhaustive (Calderon 2004); only the two most sensitive results are presented (Fig. 9).

The most sensitive parameters were recharge followed by the hydraulic conductivity of the upper three layers. Simultaneously increasing or decreasing both hydraulic conductivity and recharge caused major changes in discharge to the rivers demonstrating that the nonuniqueness commonly associated with a constant discharge/transmissivity $(Q / T)$ ratio has been reduced by including base flow measurements as a calibration target and performance indicator.

Correlated changes in hydraulic conductivity and recharge affected the model output more significantly than independent variations. To a lesser degree, the model was sensitive to, in decreasing order of sensitivity, the riverbed conductance (CRIV) and the poorly constrained location of the interface between the upper and lower parts of the Las Sierras Formation and the specific yield.

\section{Simulations}

A transient simulation was carried out to estimate the effects of future increases in groundwater extractions. Using the recharge conditions from the 2004-2005 model, groundwater extraction was increased by $100 \%$.

The results showed that the modeled hydraulic heads are not significantly affected by changes in groundwater extraction, but river base flow responds significantly to these changes (Fig. 10). Increased pumping induces discharge from some segments of the rivers into the aquifer and decreases base flow to the rivers, thus reducing the total river discharge. The relative stability of the modeled heads is due to the strong control exerted by the river boundary conditions that represent the bounding rivers and the river nodes that represent the

Table 2 River base flow results

\begin{tabular}{llll}
\hline & $\begin{array}{l}\text { Posoltega River } \\
\text { average discharge } \\
\left(\mathrm{m}^{3} / \text { day) }\right.\end{array}$ & $\begin{array}{l}\text { Residual (\%) } \\
\text { calculated-observed }\end{array}$ & \\
\cline { 2 - 3 } Model & Simulated & Observed & \\
\hline $\begin{array}{c}\text { Transient } \\
1970-1971\end{array}$ & 254,800 & 204,400 & 25 \\
$\begin{array}{c}\text { Transient } \\
\text { 2004-2005 }\end{array}$ & 170,000 & 125,600 & 35 \\
\hline
\end{tabular}

interior rivers. On the other hand, river base flow is very sensitive to any change in pumping or recharge because of the strong connection between the aquifer and the rivers.

Transient state simulations indicated that increased groundwater extraction critically affects river base flow during the dry season. Absence of runoff and high pumping stresses during dry periods can reduce river base flow to a minimum. River base flow results from three scenarios were compared: pumping conditions from 1970-1971, pumping conditions from 2004-2005 and additional groundwater development $(100 \%$ increase from 2004-2005). The results (Fig. 10, Table 2) show not only that average base flow has decreased from 1970-1971 to 2004-2005 but also that base flow decrease is most critical during dry months (December to April). Under the same recharge conditions, additional groundwater extraction may cause extreme effects on the rivers during the dry season such as a total absence of base flow (Fig. 10). Given the large agricultural and human waste loads to the river, these low base flow volumes will inevitably lead to very serious water quality issues.

Rivers control the hydraulic heads in the groundwater model, allowing only small fluctuations in level. However, in reality, once river discharge decreases, the river stage decreases, and there will be a decrease in hydraulic head. The current model cannot simulate the river stage vs. river discharge and the varying heads at the river boundaries. Developing these relationships is the focus of future research. Consequently, as the river discharge declines, the real water table will decline and, as river reaches dry up, the decline will accelerate. Declining water tables would initially affect shallow wells, but as groundwater extraction proceeds deeper wells will also be affected. Mixing of the shallow and the deep flow systems would also be expected, which is a great concern, since the water quality of the shallow flow system is poor due to the impact of agriculture and other anthropogenic sources of contamination. Thus, the quality of groundwater extracted from deep water supply wells would decline affecting human health. Induced discharge from rivers into wells is also a concern considering the exposure of river water to human and animal sources of contamination. Furthermore, a decrease in hydraulic heads in the coastal area could eventually lead to seawater intrusion.

The results from simulation scenario 1 were used to establish groundwater flow paths. Groundwater flow to wells was simulated using particle tracking (Fig. 11). The results are consistent with the existence of the previously hypothesized deep flow system (United Nations 1974; Payne and Yurtsever 1974). Water from the deep flow system is captured by deep wells (Fig. 11, wells 1 and 2) and water from the shallow flow system is captured by intermediate depth and shallow wells (Fig. 11, wells 3, 4 and 5). Mixing of deep and shallow groundwater occurs in the intermediate depth wells, located in the central plain (Fig. 11, well 3). River discharge is also captured by wells located near the rivers. The shallow wells located in the lower plain capture locally recharged groundwater. 
Fig. 6 River base flow $(Q)$ calibration for 2004-2005 model

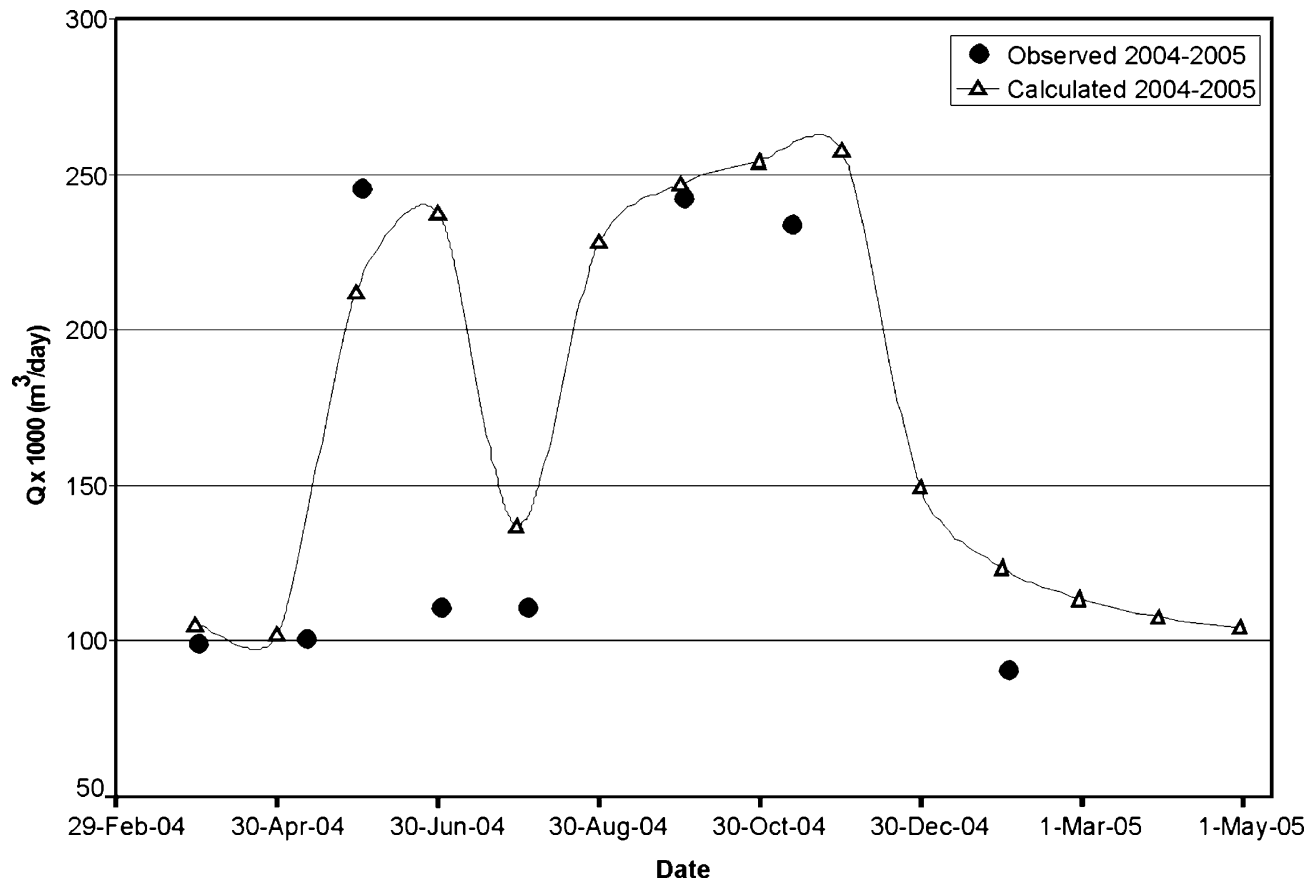

\section{Model limitations}

Although the model calibration was satisfactory, the numerical model does have limitations.

\section{Measurement distributions}

Transmissivity measurements were more abundant for the productive Quaternary deposits and upper Las Sierras Formation with 28 and 21 values, respectively. On the other hand, only five values were available for the lower Las Sierras Formation, which is much less productive. Furthermore, within the upper layers, the data are unevenly distributed and more measurements are concen- trated in the center of the study area. The uneven distribution is due to the concentration of irrigation wells in the most cultivated area. This situation increases the uncertainty of hydraulic conductivity values in the higher elevation areas and in the lower Las Sierras Formation. Although the data in the lower Las Sierras Formation is scarce, it is clear that conductivity is low compared to the upper layers where most flow is channeled. Thus, the sensitivity analysis indicates that the model results are not sensitive to the hydraulic conductivity of this layer. Another concern about initial data is related to the time span of observations used for calibrating the transient state model. Data are from one hydrologic year, since there

Fig. 7 Hydraulic head values starting from steady-state initial conditions and repeating the 1970-1971 model year recharge and pumping stresses for 10 years. The influence of the initial conditions is not evident after the first simulated year

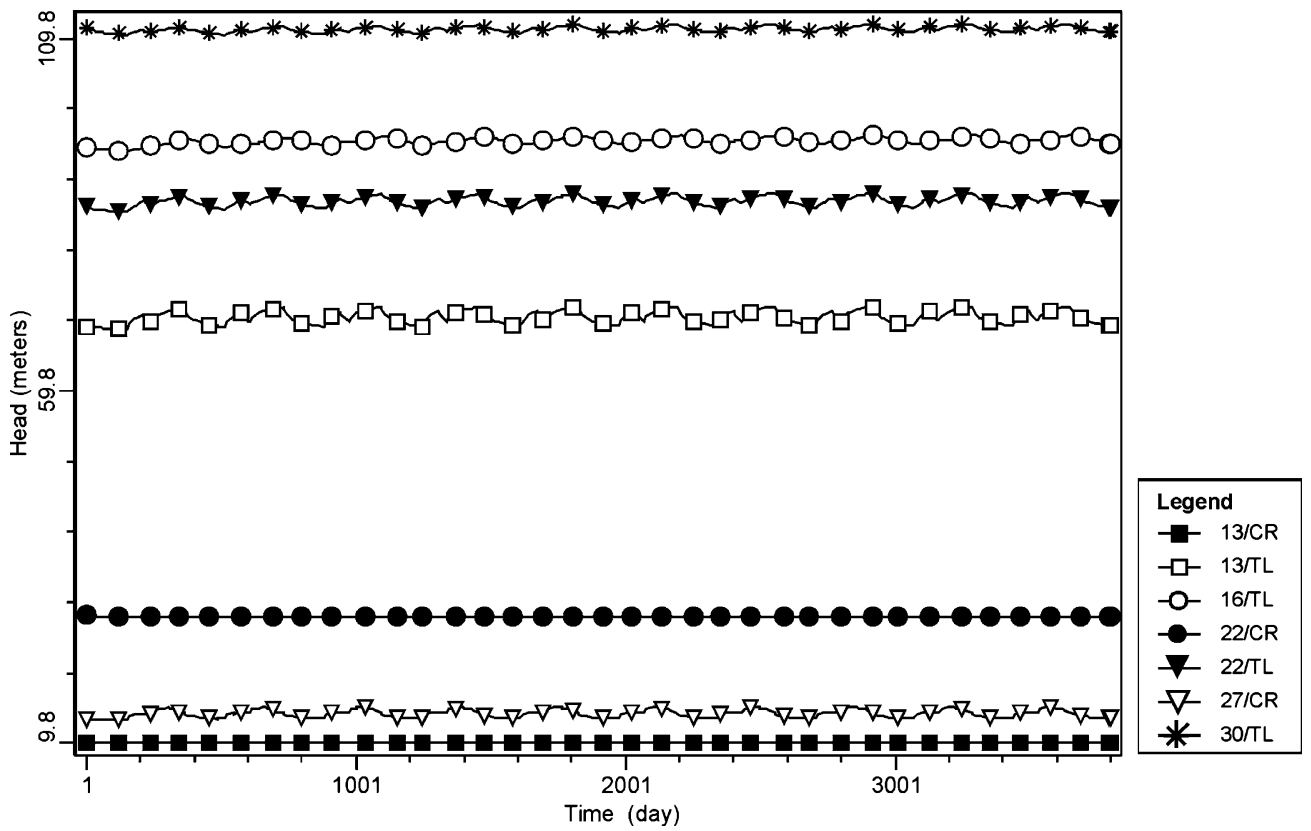


Fig. 8 Hydraulic head fluctuations for upland wells (19701971 model). Results are shown for the tenth cycle

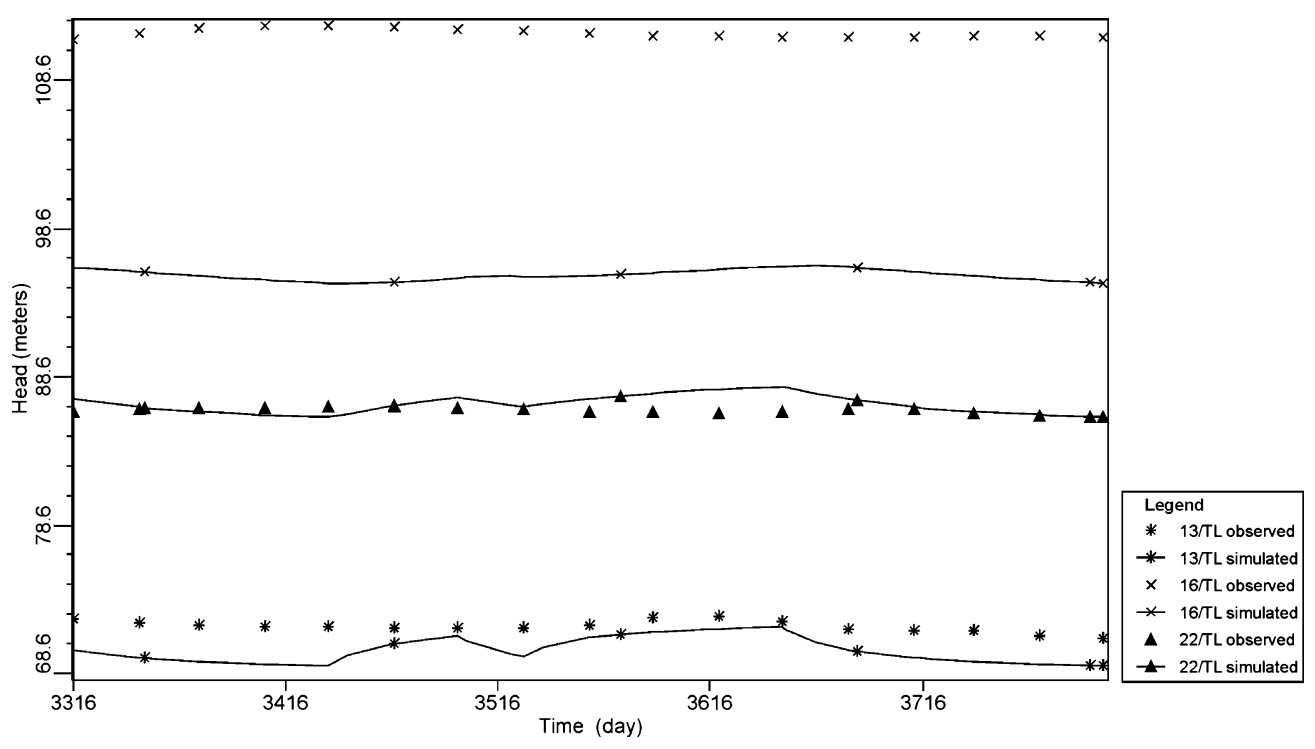

were no long-term data. This might be a source of uncertainty since it can prevent the model from capturing long-term fluctuations. However, the model indicates that the system memory is short, in the order of 1 year.

\section{Seawater intrusion}

MODFLOW does not account for density dependent flow and is not appropriate for modeling the possibility of seawater intrusion. This is a limitation of the model, since an increase in groundwater extraction might lead to seawater intrusion. However, careful examination of mod- eled hydraulic heads and seaward discharge values can produce useful indications or warnings of this problem.

\section{Non-physical results}

Due to the proximity of the water table to the ground surface in the coastal area, it is possible that errors in hydraulic heads could lead to non-physical results such as an indication of flooding over these areas. This has to be considered when examining the results of the regional model. In addition, at some point, pumping can become so severe that the river flows cease. At this point, the river
Fig. 9 a Sensitivity analysis for recharge. b Sensitivity analysis for conductivity $K$ of layer 1
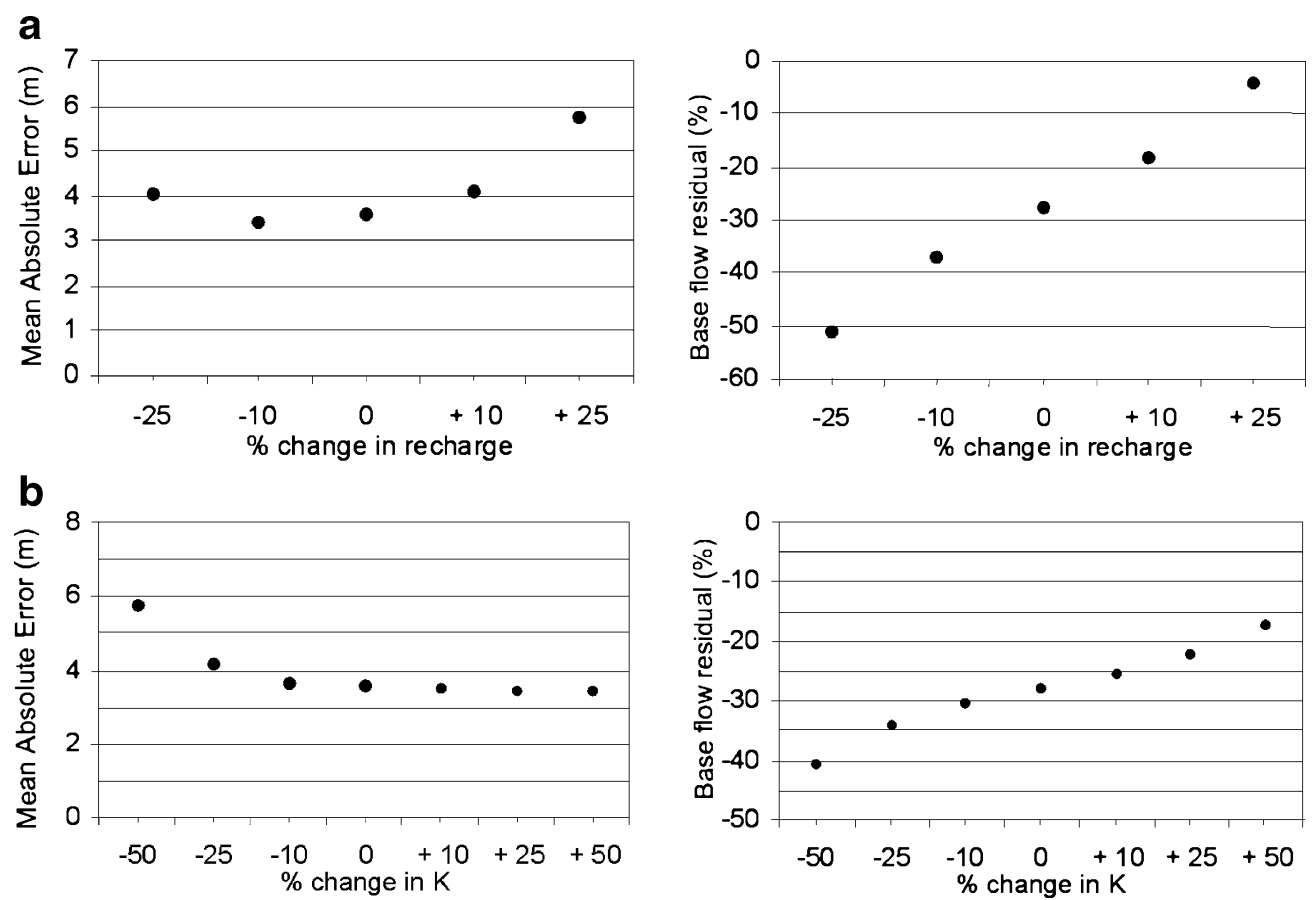
Fig. 10 River base flow $(Q)$ simulations for 1970-1971, 2004-2005 and $100 \%$ increase in groundwater $(\mathrm{GW})$ extraction. Negative figures indicate a total absence of base flow

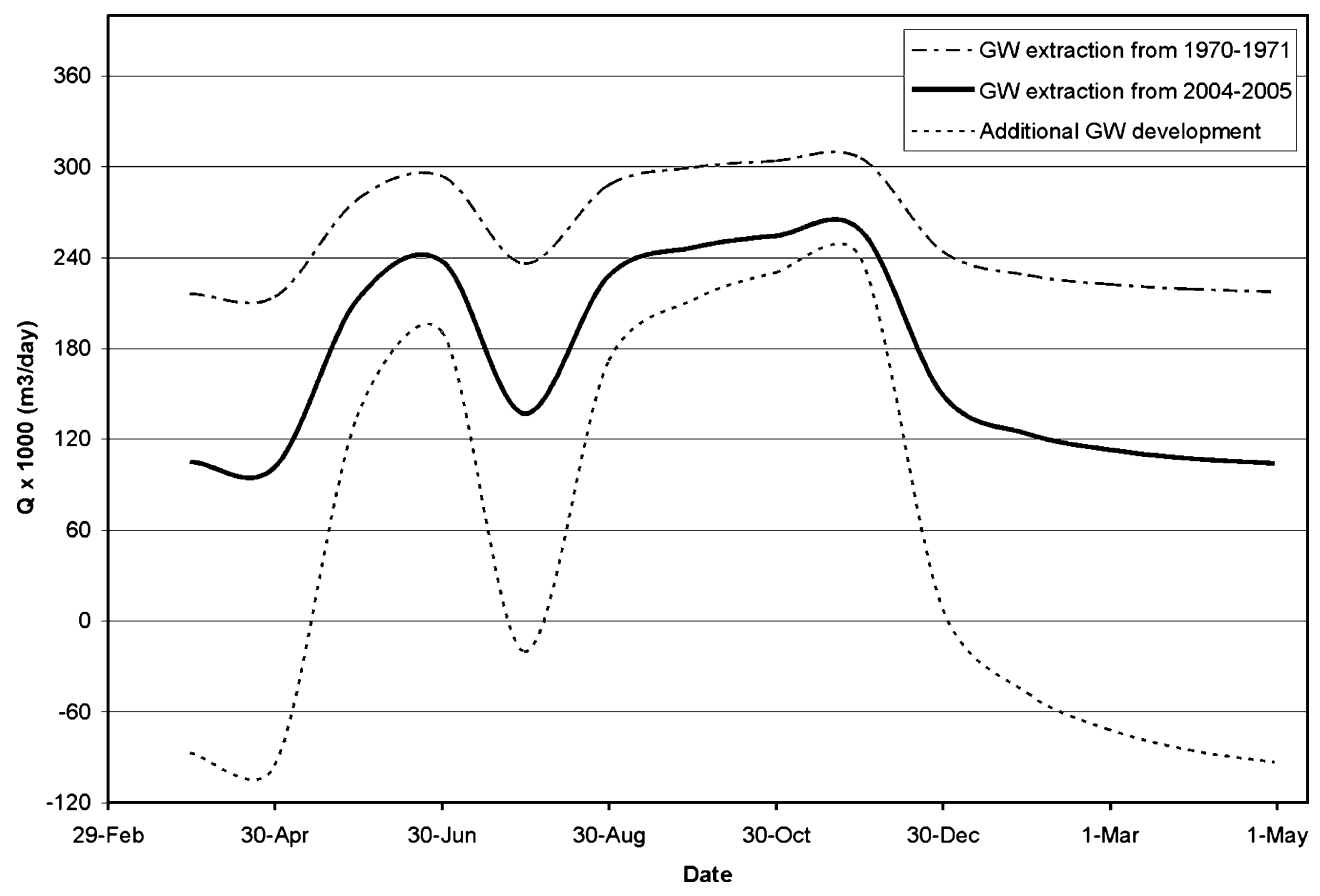

boundary conditions will artificially support the modeled heads, when in reality they start to decline more rapidly.

\section{Conclusion}

Groundwater models are an important tool for demonstrating a quantitative understanding of a hydrogeologic system that is consistent with the current available data. Producing a calibrated and validated groundwater model provides a level of confidence in the conceptual model of the main physical processes and forcings that are controlling hydraulic heads and fluxes. In addition, model sensitivity analysis is a useful tool for identifying the most critical parameters of the hydrogeologic system. Identifying the most critical parameters allows for efficient resource allocation for field-monitoring activities, which is highly important for fund-limited research. In this case, the approach identified river discharge as the key measurement needed to constrain recharge, which was the largest source of uncertainty in the model.

Simulated hydraulic heads are controlled by the rivers in the model, allowing only small fluctuations in their values. Thus, changing stresses such as increased pumping, only slightly affects the simulated water table surface. However, river base flow is very responsive to these changes, especially during dry periods. Increased pumping induces more discharge from the rivers into the aquifer and decreases base flow, reducing the total river discharge.

Past work has used steady-state models. However steadystate models are limited in usefulness because of the major differences in recharge and pumping between the wet and dry seasons. Transient state simulations indicated that increased groundwater extraction critically affects river base flow during the dry season. The decrease in river flow will lead to a decline in river-water quality. In addition, as river flow decreases, the river stage will also decrease. Although not properly captured by the current model, the heads would eventually drop, especially as some reaches of the river become dry. The decline in the water table would initially affect shallow wells, but as groundwater extraction proceeds deeper wells will also be affected. As these impacts are very important, future work should address coupled surface water-groundwater modeling to properly capture the relationships of hydraulic head to river flow and river stage.

Two different flow systems are identified in the LeonChinandega aquifer. The first one is a deep system, recharged in the cordillera and then discharged in the central and lower plain, either as base flow or to pumping wells. The second is a shallow local flow system, recharged in the central and lower plain which is discharged into the rivers or pumping wells. Simulations indicated that groundwater from deep wells is recharged at high elevations, corresponding to the deep flow system. Shallow wells mostly capture groundwater that is recharged locally, but there was also an indication that mixing of the regional and local system can occur.

More mixing of the shallow and the deep flow systems could occur if base flow decreases excessively and heads start fluctuating freely. The mixing of these flow systems is a great concern since the water quality of the shallow flow system is poor due to the impact of agriculture. Induced river-water discharge into wells is also a concern because of its poor quality. Another possible negative consequence is seawater intrusion, which can occur if head gradient along the coastal area declines.

All of the above stress the importance of properly managing the aquifer. The simulation results indicate that the system response time is in the order of a year. Conse- 


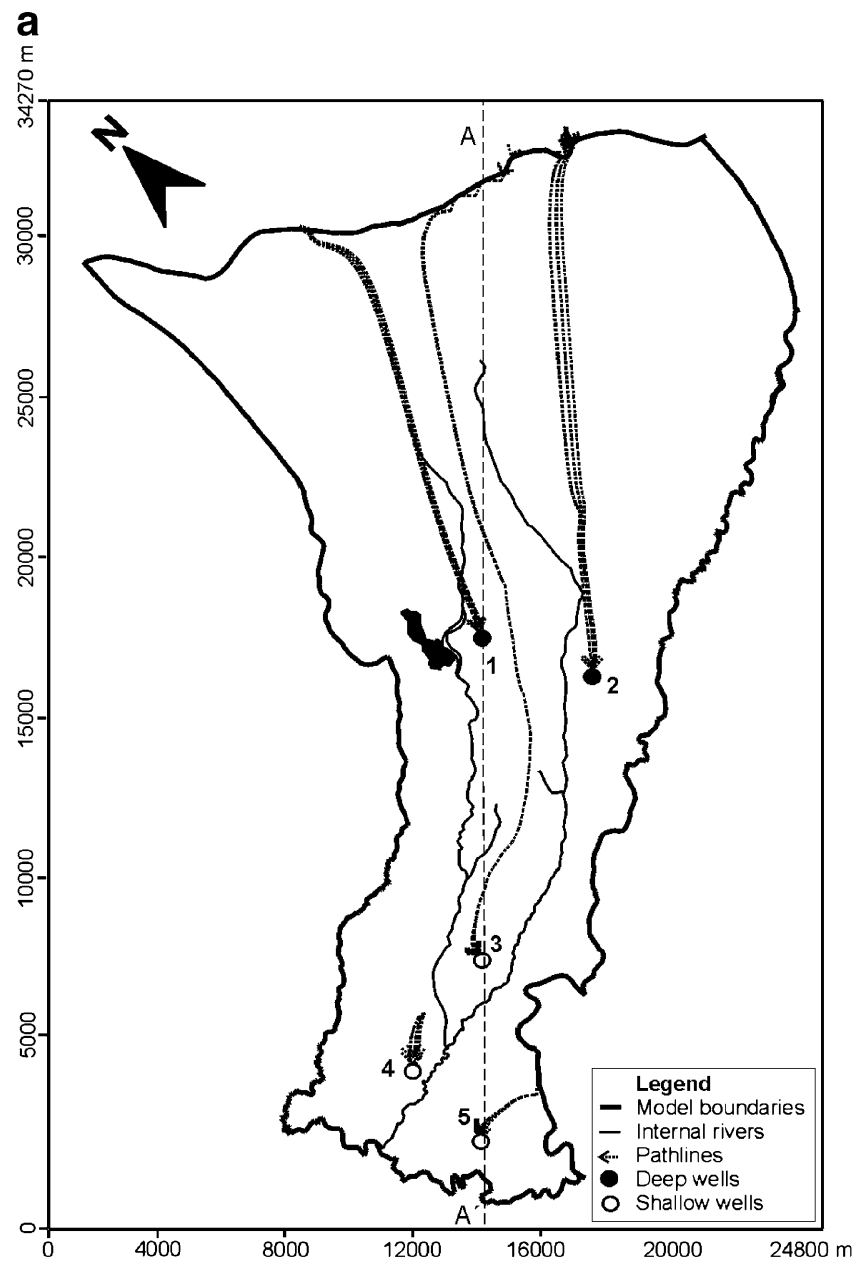

b

$A^{\prime}$

A

品-

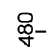

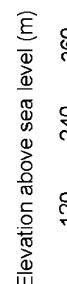

:

-

5000

Fig. 11 Particle tracking results: a plan view and $\mathbf{b}$ cross section

quently, management strategies need to be conservative or implemented in a dynamic adaptive manner. Clearly, steadystate simulations cannot capture certain critical aspects of the groundwater system and transient simulations are required to estimate important hydrological factors such as minimum base flow. Insight into these critical periods of highest stresses is only possible through transient simulations. The assessment of possible groundwater development scenarios 
is now possible through transient simulations. Considering the potential development of more intensive and sophisticated irrigated agriculture in the Leon-Chinandega region, the numerical model becomes a powerful tool for water resources management.

Acknowledgements Funding for this research was provided by the Central American Water Resources Management Network (CARA Project), sponsored by the Canadian International Development Agency. Many thanks to The Nicaraguan Aquatic Resources Research Center of the National Autonomous University of Nicaragua (CIRA/ UNAN-Managua) for the continual support given to this project.

\section{References}

Anderson MP, Woessner WW (1992) Applied groundwater modeling: simulation of flow and advective transport. Academic Press, San Diego, CA

Briemberg J (1994) An investigation of pesticide contamination of groundwater sources for urban water distribution systems in the Pacific Region of Nicaragua. Final report 3. CIDA Awards for Canadians, CIDA, Gatineau, QB

Calderon $H$ (2004) Numerical modeling of the groundwater flow system in a sub-basin of the Leon-Chinandega aquifer, Nicaragua. MSc Thesis, University of Calgary, Calgary, AB

Carvalho FP, Montenegro-Guillen S, Villeneuve J-P, Cattini C, Bartocci J, Lacayo M, Cruz A (1999) Chlorinated hydrocarbons in coastal lagoons of the Pacific coast of Nicaragua. Arch Environ Contam Toxicol 36:132-139

Castillo JA (1994) Niveis de contaminacao das aguas da bacia do rio Atoya por residuos de pesticidas organoclorados e organofosforados aplicados na cultura do algodao [Contamination levels in the Atoya River from organochlorine and organophosphate pesticides used in cotton cultivation]. Universidad Federal do Pará, Brazil

Centro Humboldt (2001) Caracterización hidrogeológica, hidroquímica, bacteriológica y de plaguicidas en las aguas subterráneas del municipio de Posoltega [Hydrogeological, hydrochemical, bacteriological and pesticide characterization of Posoltega groundwaters]. Managua, Nicaragua

Centro para la Investigacion en Recursos Acuaticos de Nicaragua (CIRA/UNAN-Managua; 1999a) Diagnóstico de la calidad toxicológica de las aguas y suelos y calidad bacteriológica de las aguas del municipio de Posoltega [Toxicological quality of soils and water and bacteriological quality of water from Posoltega]. CIRA/UNAN, Managua, Nicaragua

Centro para la Investigacion en Recursos Acuaticos de Nicaragua (CIRA/UNAN-Managua; 1999b) Proyecto ARCAL XXXI. Caracterización de los acuíferos para la gestión sustentable de los recursos hídricos subterráneos en áreas urbanas. Informe Nicaragua. Estudio isotópico y de la contaminación del acuífero
León-Chinandega. [Aquifer characterization for sustainable groundwater management in urban areas. Isotopic study of the contamination in the León-Chinandega aquifer]. CIRA/UNAN, Managua, Nicaragua

Corriols M (2003) Hydrological, geophysical and hydrochemical investigations in the Leon-Chinandega Plains, Nicaragua. Licentiate Thesis. Lund University, Sweden

Delgado V (2003) Groundwater flow system and water quality in a coastal plain aquifer in northwestern Nicaragua. MSc Thesis, University of Calgary, Canada

Fenzl N (1985) Sea water intrusion in coastal aquifer of the LeonChinandega region (in Portuguese). Rev Assoc Brasil Águas Subterrân 9:61-80

Forster C, Smith L (1988a) Groundwater flow systems in mountainous terrain, 1: numerical modeling technique. Water Resour Res 24(7):999-1010

Forster C, Smith L (1988b) Groundwater flow systems in mountainous terrain, 2: controlling factors. Water Resour Res 24(7):1011-1023

Freeze RA, Cherry JA (1979) Groundwater. Prentice-Hall, Englewood Cliffs, NJ

INETER (2000) Estudios hidrológicos e hidrogeológicos en la región del Pacífico de Nicaragua: fase I Región ChinandegaLeón-Nagarote [Hydrological and hydrogeological studies in the Pacific Region of Nicaragua: phase I Chinandega-LeónNagarote region), vols 1-3. Prepared for MAGFOR, INETER, Managua, Nicaragua

Izbicki JA, Radyk J, Michel RL (2000) Water movement through a thick unsaturated zone underlaying an intermittent stream in the western Mojave Desert, southern California, USA. J Hydrol 238 (3-4):194-217

Izbicki JA, Radyk J, Michel RL (2002) Movement of water through the thick unsaturated zone underlying Oro Grande and Sheep Creek Washes in the western Mojave Desert, USA. Hydrogeol J 10(3):409-427

McDonald MG, Harbaugh AW (1988) A modular three-dimensional finite-difference groundwater flow model. US Geol Surv Open File 83-0875, US Geological Survey, Reston, VA

Moncrieff J (2006) Modelling as a tool in the understanding and protection of groundwater in the León-Chinandega region of Nicaragua, MSc Thesis, University of Calgary, Canada

Neuman SP (1975) Analysis of pumping test data from anisotropic unconfined aquifers considering delayed gravity response. Water Resour Res 11(2):329-342

Payne BR, Yurtsever Y (1974) Environmental isotopes as a hydrogeological tool in Nicaragua. In: Isotope techniques in groundwater hydrology. Proceedings of an International Symposium Vienna, Austria, 11-15 March 1974, International Atomic Energy Agency, Vienna

Stephens DB (1996) Vadose zone hydrology. CRC, Boca Raton, FL

United Nations (1974) Investigaciones de aguas subterráneas en la región de la Costa del Pacífico. Zona de Chinandega [Groundwater research in the Pacific Coast region. Chinandega area], vol I and II. UN, New York 